\title{
Proliferating cell nuclear antigen in oesophageal diseases; correlation with transforming growth factor alpha expression
}

\author{
J Jankowski, R McMenemin, C Yu, D Hopwood, K G Wormsley
}

\begin{abstract}
This study was designed to correlate mucosal proliferation in Barrett's oesophagus with expression of a growth promoting peptide, transforming growth factor alpha (TGF $\alpha$ ). Oesophageal mucosa was studied from 50 patients with oesophageal disease who had been treated by oesophagectomy. Histological analysis showed a range of oesophageal pathology - 18 patients had gastric type Barrett's mucosa, 18 had intestinal type Barrett's mucosa, and 14 had oesophageal adenocarcinomas. Sections were stained immunohistochemically for proliferating cell nuclear antigen (PCNA) (an index of cellular proliferation) and TGF $\alpha$. PCNA immunostaining was seen mainly in the basal cells of the neck/foveolar epithelial compartment of the glands in Barrett's oesophagus. However, in mucosa with high grade dysplasia, the proliferative compartment extended upwards into the superficial layers of the glands. At least 2000 cells were counted in each patient to determine the proportion with PCNA immunoreactivity (PCNA labelling index). The labelling index was highest in adenocarcinoma (25\%) and in Barrett's intestinal type mucosa with high grade dysplasia (26\%) compared with intestinal type mucosa with no significant dysplasia $(20 \%)$ and Barrett's gastric type mucosa (12\%). There was a significant positive correlation between PCNA labelling indices and TGF $\alpha$ expression in Barrett's mucosa $(p<0 \cdot 01)$. In glands showing high grade dysplasia, TGF $\alpha$ immunoreactivity was seen in the same regions of the glands as PCNA immunoreactivity, indicating the possibility of involvement of TGF $\alpha$ in (pre) neoplastic proliferation in Barrett's oesophagus.
\end{abstract}

In 1950, Norman Barrett drew attention to a condition in which the lower portion of the oesophagus was lined by columnar epithelium. ${ }^{\prime}$ Subsequently it has been recognised that - Barrett's mucosa has a 30-40 fold increased risk of developing adenocarcinoma compared with the normal oesophagus, ${ }^{2}$ while adenocarcinomas arising in the oesophagus are mostly associated with surrounding Barrett's columnar lined mucosa. ${ }^{2}$ Moreover, it has been reported that the incidence of oesophageal adenocarcinoma has recently been increasing throughout Britain and the USA.$^{3+}$ It seems possible that the process of oesophageal carcinogenesis involves the replacement of inflamed squamous mucosa by metaplastic columnar lined mucosa, with eventual development of high grade dysplasia or carcinoma in situ (the metaplasia-dysplasia- carcinoma sequence).${ }^{56}$ However, it is not known what factors determine the progression from inflamed mucosa to metaplastic, dysplastic, and frankly carcinomatous mucosal cells.

Until recently, proliferative indices have been assessed by in vitro methods such as labelling with tritiated thymidine or bromodeoxyuridine. ${ }^{78}$ Recently, a new antibody to proliferating cell nuclear antigen (PCNA), an auxillary protein for DNA synthetase," has been described. ${ }^{111}$ This antibody, designated PC10, allows ex-vivo proliferative indices to be assessed in formalin fixed tissues. ${ }^{1213}$

Although the mechanisms underlying oesophageal carcinogenesis are not known, it has been reported previously that transforming growth factor alpha (TGF $\alpha$ ) exerts mitogenic and oncogenic effects on the alimentary tract, including the oesophagus, stomach, and pancreas. ${ }^{1+16} \mathrm{~A}$ further link with PCNA expression depends on the finding that growth factors can induce PCNA mRNA stability, and consequently, PCNA expression. ${ }^{16}$

In this study, therefore, our aim was to assess proliferation in benign and malignant oesophageal mucosa using PCNA immunostaining as an index of proliferation, and to correlate the latter with expression of one of the peptides, TGF $\alpha$, thought to be involved in mitogenesis and carcinogenesis.

\section{Patients and methods}

Fifty patients who had undergone oesophageal resection for oesophageal carcinoma, dysplasia in Barrett's oesophagus, or benign peptic strictures had serial $6 \mu \mathrm{m}$ sections taken from available paraffin embedded blocks.

Routine histological assessment was performed on sections stained with haematoxylin and eosin. The sections were graded for metaplasia and dysplasia according to the criteria of Whitehead ${ }^{17}$ and Riddell, ${ }^{18}{ }^{18}$ respectively. Sections that had predominantly one type of metaplastic epithelium, involving more than $95 \%$ of the mucosal surface, were selected. Sections with Barrett's epithelium were divided into three groups: Barrett's gastric type mucosa (fundic or cardiac); Barrett's intestinal type mucosa; and adenocarcinoma arising in Barrett's oesophagus.

The monoclonal antibody, PC10, was applied to serial paraffin sections from the selected tissue blocks as described previously. ${ }^{19}$ All sections were dewaxed and air dried at room temperature. The antibody was used at a dilution of 1:200 with overnight incubation. Immunoperoxidase staining was carried out by the modified streptavidine sABC method. Sections of lymph nodes from 
$\underline{\text { Regional proliferation in Barrett's mucosa }}$

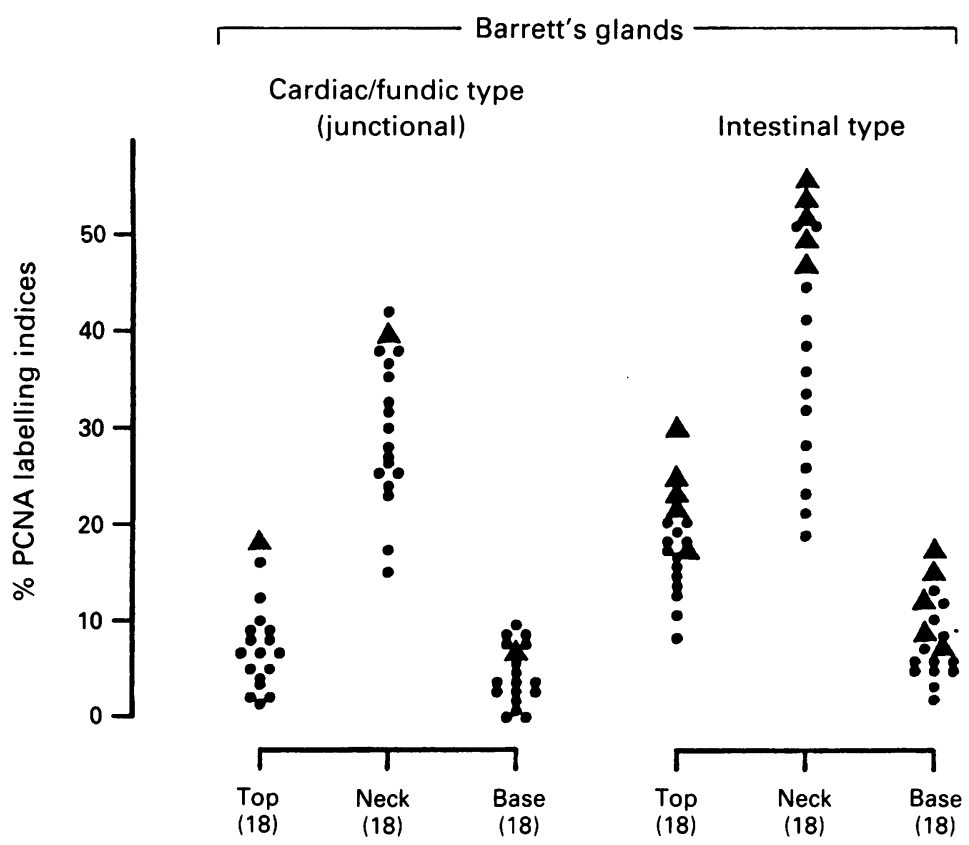

Region of gland

A High grade dysplasia

Figure 1: PCNA labelling indices in different regions of the Barrett's glands.

patients with lymphoma were included as positive controls. ${ }^{13}$ The number of cells with positive PCNA staining was counted in a minimum of 2000 nucleated epithelial cells (a minimum of 40 crypts) and expressed as a percentage of the total number of cells counted (PCNA labelling index). The labelling indices were determined separately in each of the three levels in the glands - superficial cells, neck/isthmus compartment, and base of the gland. The overall labelling index for each gland was also calculated from the total number of positive cells in all three levels, expressed as a percentage of all cells counted. Additional serial sections from the same blocks were stained immunohistochemically with a monoclonal antibody to TGF $\alpha$ in a dilution of 1:200 with overnight incubation. The TGF $\alpha$ antibody is an IgG monoclonal antibody (Oncogene Science, Manhasset New York).

Negative control sections included sections of Barrett's oesophagus and pancreatic cancer which were incubated overnight with an excess of TGF $\alpha$ peptide $1 \mu \mathrm{g} / \mathrm{ml}$ (Sigma) and TGF $\alpha$ antibody. The technique is designed to assess the specificity of the antibody by demonstrating staining of proteins other than $\mathrm{TGF} \alpha$ alone (absorbance reaction).

Positive control studies included duplicate sections of pancreatic carcinoma which were stained with a monoclonal TGF $\alpha$ antibody and a polyclonal TGF $\alpha$ antibody (26T, gift from Dr W Gullick ICRF).

The sections were graded according to the intensity of cytoplasmic staining for TGF $\alpha$ by examination of at least 1000 consecutive nucleated epithelial cells, which were independently assessed by two observers. The sections were considered positive only if the number of epithelial cells which had at least $1+$ staining was greater than $10 \%$ of the total epithelial cells. The intensity of staining was graded as 0 -III $(0=$ no staining, $\mathrm{I}+=$ weakly positive, $\mathrm{II}+=$ moderately positive (cytoplasm positive but other cytoplasmic details also visible), and III $+=$ strongly positive (entire cytoplasm densely stained)). The grade considered to be $\mathrm{III}+$ stained as densely as simultaneously stained (control) pancreatic carcinoma. ${ }^{1416}$

In some sections $\mathrm{TGF} \alpha$ antibody produced membranous staining in addition to cytoplasmic staining and this finding was noted separately. In some cases the staining intensity was not uniform within a gland and a mean intensity per section

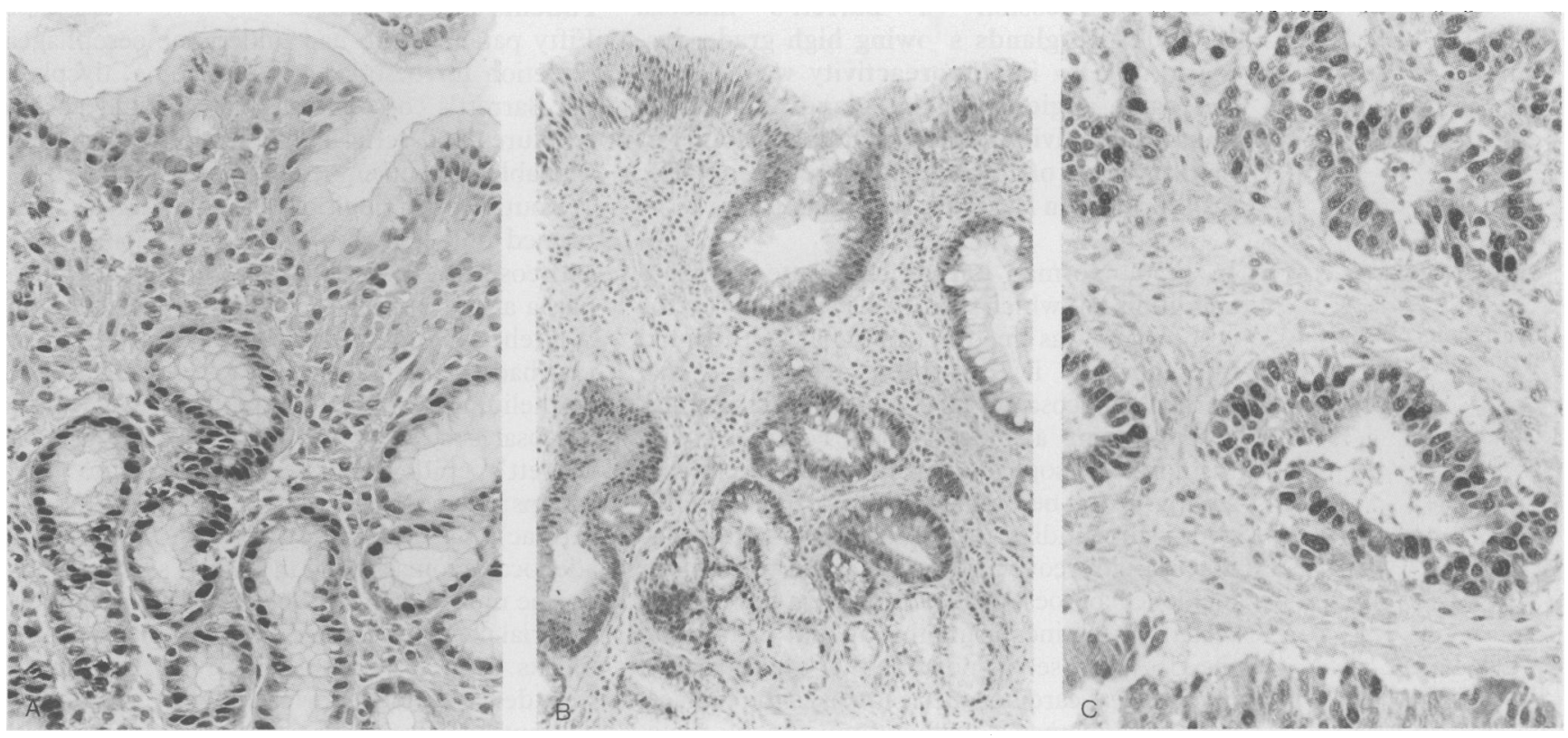

Figure 2: (A) Photomicrograph of PCNA labelling in Barrett's mucosa with fundic type metaplasia (original magnification $\times 285$ ). (B) Photomicrograph of $P C N A$ labelling in Barrett's mucosa with intestinal-type metaplasia (original magnification $\times 225$ ). (PCNA positive cells extend into the superficial and deep glandular compartments of the epithelium). (C) Photomicrograph of PCNA labelling in Barrett's adenocarcinoma (original magnification $\times 450$ )

(C) Photomicrograph of PCNA labelling in Barrett's adenocarcinoma (original magnification $\times 450$ ). 


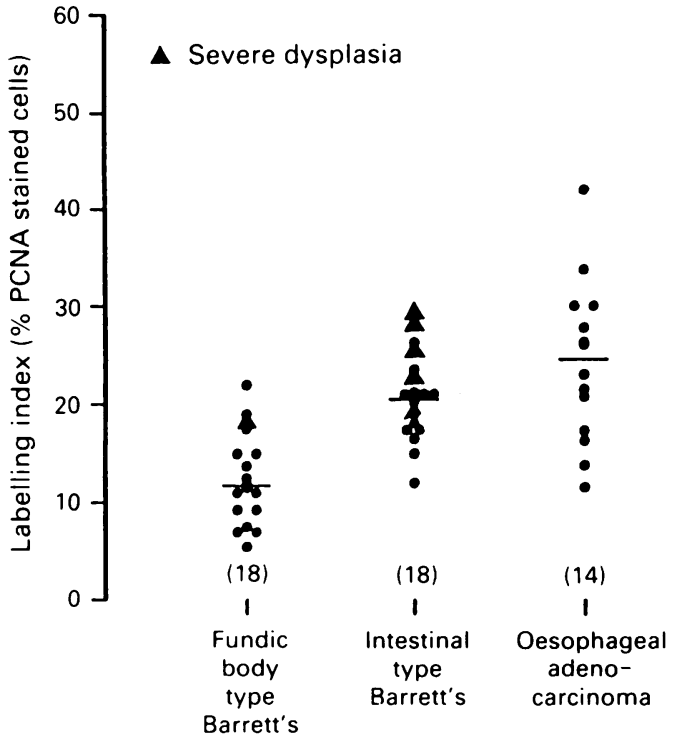

Figure 3: PCNA labelling indices in different types of Barrett's mucosa.

was calculated by taking into account the number of cells showing each of the different grades. For example if 1000 cells were counted in one section and the number of cells of each intensity was as follows; $0=10, I=40, I I=550, I I I=400$, the mean count was calculated by averaging the sums of $(0 \times 10)+(1 \times 40)+(2 \times 550)+(3 \times 400)=2340 /$ 1000. The mean intensity in this section was rounded down to 'II'.

We validated our counts for both PCNA labelling and TGF $\alpha$ expression. Two individuals performed a second independent count on sections of mucosa, immunostained for PCNA and TGF $\alpha$ respectively, without knowledge of the results of the first counts. There was less than $5 \%$ variation from the initial calculations.

Regional TGF $\alpha$ expression in Barrett's mucosa

Barrett's glands
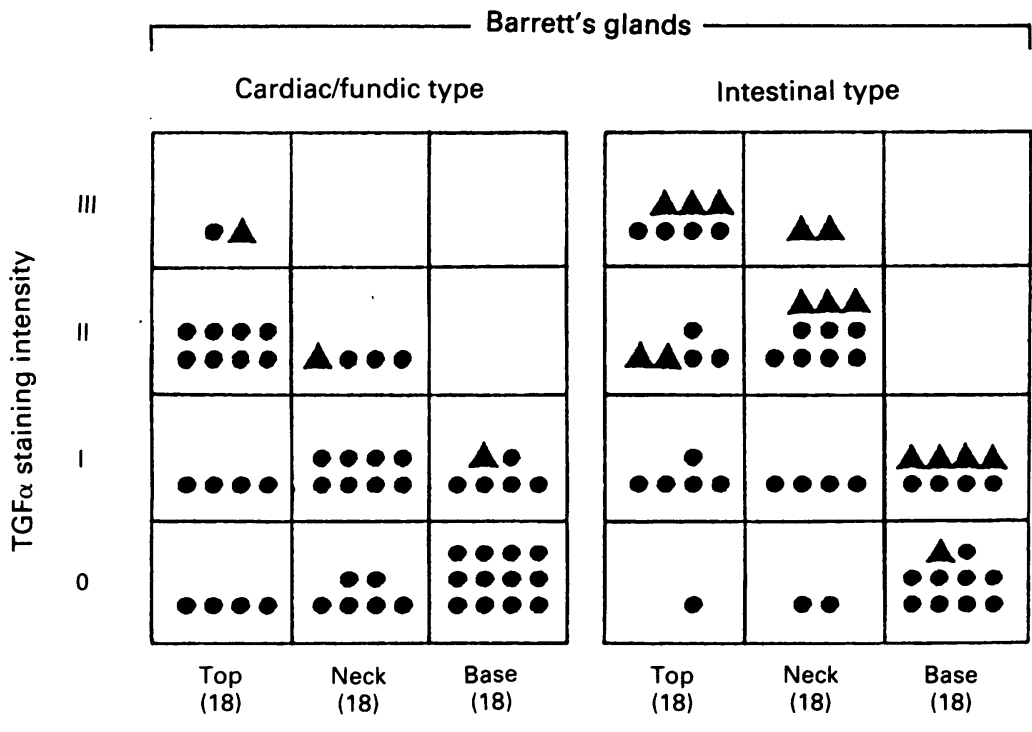

Region of gland

Aigh grade dysplasia

Figure 4: TGF $\alpha$ expression in different regions of Barrett's mucosa.
STATISTICS

The data were not normally distributed, so that the Kruskal-Wallis analysis of variance was used to compare intragroup variation with intergroup variation of PCNA and TGF $\alpha$ labelling.

Correlation analysis was used to compare the PCNA 'labelling' with the expression of TGF $\alpha$.

The Wilcoxon-rank test was used to assess the difference in expression of TGF $\alpha$ and PCNA between high grade dysplasias and those with no dysplasia in relation to PCNA and TGF $\alpha$ expression.

\section{Results}

Eighteen patients had Barrett's cardiac or fundic type mucosa, (one also showed high grade dysplasia), 18 patients had Barrett's intestinal types mucosa (five with high grade dysplasia), and 14 patients had adenocarcinoma.

\section{PCNA LABELLING}

PCNA labelling indices in glandular tissue were highest in the neck/isthmus of the glands (Fig 1). The overall glandular PCNA cell counts were found to correlate with different types of mucosal metaplasia. Gastric (fundic/cardiac) Barrett's mucosa had a median labelling index of $12 \%$ (range 6-23); Barrett's intestinal mucosa with and without dysplasia had a median index of $20 \%$ (range 12-30), and Barrett's adenocarcinoma had a median index of $25 \%$ (range 12-43) $(\mathrm{p}<0.05)$ (Figs 2A, B, and C). Intestinal type Barrett's mucosa with dysplasia had higher median labelling indices than intestinal type Barrett's mucosa without dysplasia $(26 \%$ and $20 \%$ respectively, $\mathrm{p}<0.05$ ). There was no significant difference between the labelling indices of cardiac or fundic type metaplastic mucosa $(p=0.6)$ (Fig 3).

In dysplastic glands, the labelling indices were higher in the superficial and deep (basal) regions of the glands compared with non-dysplastic mucosa (Fig 1).

\section{TGF $\alpha$ LABELLING}

The control slides failed to show any discernable TGF $\alpha$ immunoreactivity after application of excess TGF $\alpha$ except in 8 (16\%) sections which showed a residual membranous staining and negligible cytoplasmic staining (less than grade I).

The staining patterns of the two TGF $\alpha$ antibodies were identical.

TGF $\alpha$ staining was found to be maximal in the superficial epithelial cells (Fig 4). However, in some sections, especially those with dysplasia, TGF $\alpha$ staining could also be seen in cells sited deeper in the neck of the gland (Fig 5B).

The intensity of TGF $\alpha$ staining was significantly different in the different types of Barrett's mucosa $(p<0.01)$. Gastric (fundic/cardiac) type Barrett's mucosa showed a median grade of 1 ; while Barrett's intestinal mucosa with or without dysplasia showed a median grade of 2 . Barrett's adenocarcinoma also showed a mean grade of 2 . (Fig 6 and Figs 5A, B, and C).

The expression of TGF $\alpha$ in the superficial 

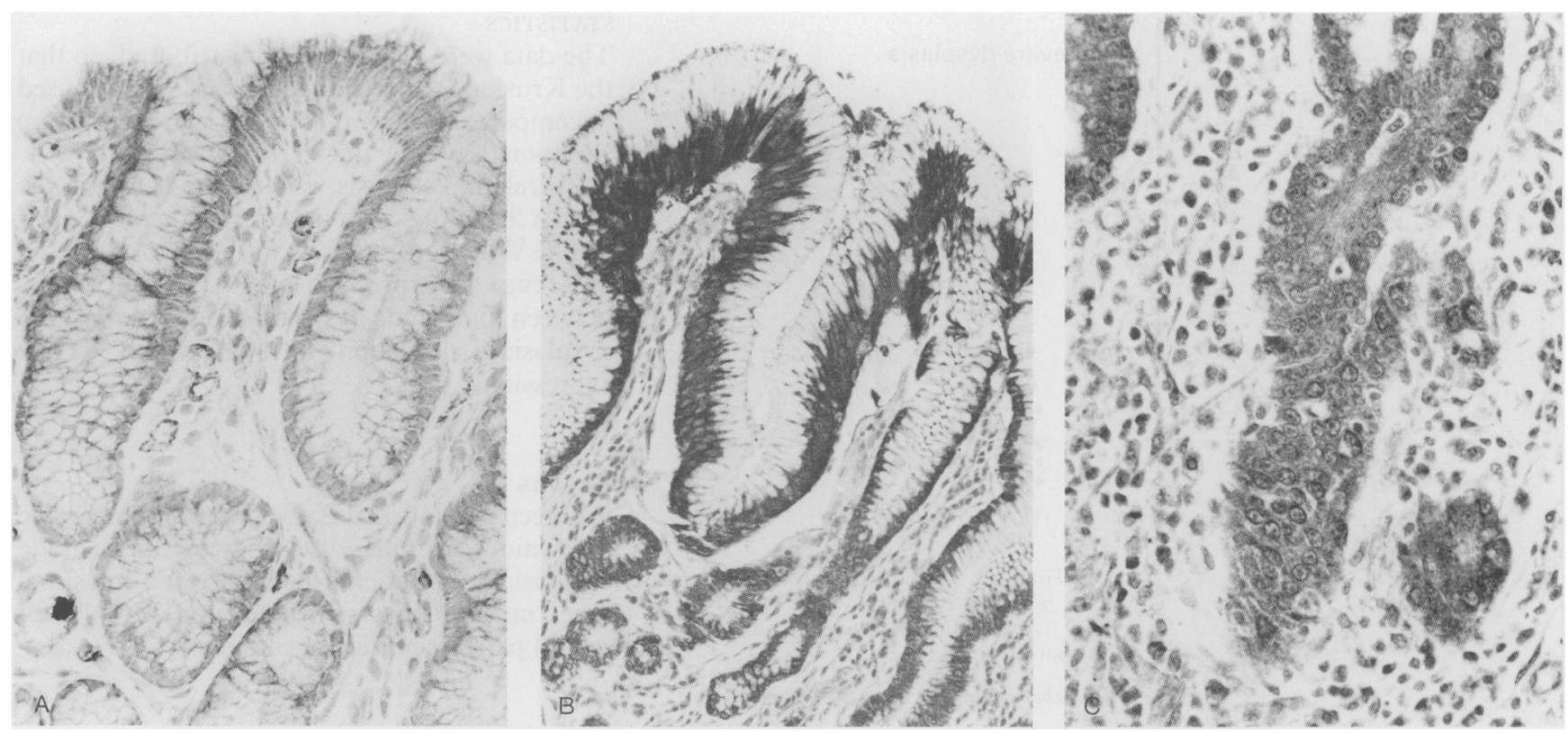

Figure 5: (A) Photomicrograph of TGF $\alpha$ expression (grade II) in Barrett's mucosa with fundic type metaplasia (original magnification $\times 450$ ).

(B) Photomicrograph of TGF $\alpha$ expression (grade III) in Barrett's mucosa with intestinal type metaplasia (original magnification $\times 450)$. (Occasional goblet cells visible in epithelium.) (C) Photomicrograph of TGF a expression (grade II) in Barrett's adenocarcinoma (original magnification $\times 450$ ).

portion of the glands correlated well with the PCNA labelling index in the entire gland (Fig 6).

Glands with PCNA immunoreactive cells in the superficial portion of the glands showed a high density of TGF $\alpha$ staining in the same region (Figs 2B and 5B).

\section{Discussion}

These findings agree with previous reports which have shown extension of the proliferative compartment from the neck to the remainder of the glands in dysplastic epithelium. There is also an increase in the overall proportion of proliferating cells in intestinal type Barrett's mucosa and
TGF $x$ expression with proliferation

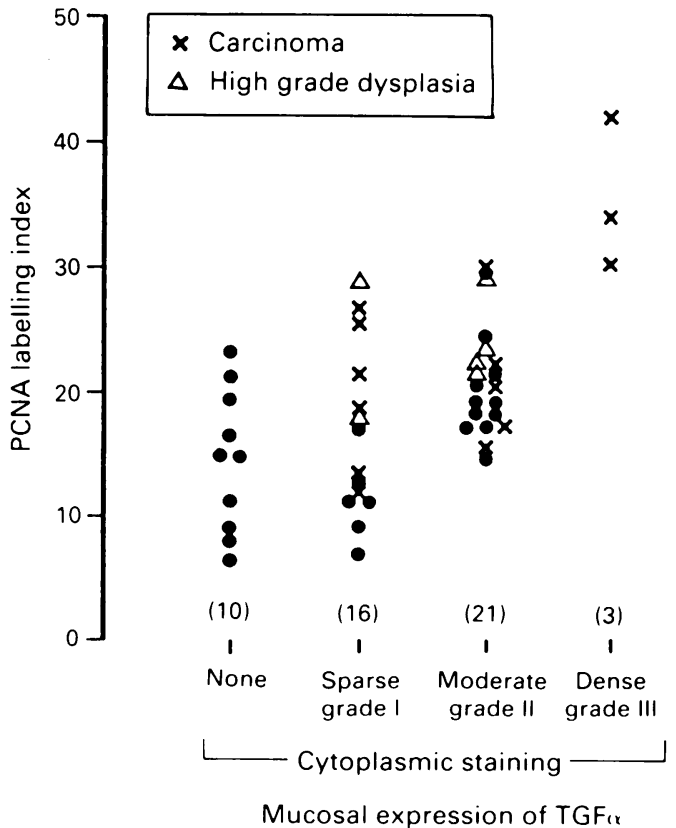

adenocarcinoma compared with the gastric type of Barrett's metaplasia. ${ }^{2021}$ The magnitude of the PCNA labelling indices is similar to those reported by Pellish et al using autoradiography. ${ }^{21}$ For example, Barrett's mucosa with intestinal metaplasia has been reported to have a labelling index of $23 \%$ using autoradiography while we have shown that the PCNA labelling index is $18 \%$ in this type of mucosa.

On the other hand, it is possible that PCNA expression is deregulated in high grade dysplastic tissue and adenocarcinomas. ${ }^{22} 23$ PCNA expression, therefore, may not necessarily correlate with proliferation in these tissues as has been reported previously. ${ }^{10}$

It has been reported previously that $\mathrm{TGF} \alpha$ is associated with mitogenesis and oncogenesis in the gastrointestinal tract. ${ }^{1+16}{ }^{2+29} \mathrm{It}$ is therefore of considerable interest that we have confirmed the presence of this peptide in Barrett's columnar mucosa and in adenocarcinoma of the oesophagus. ${ }^{16}$ Moreover, we have shown a significant correlation between intensity of TGF $\alpha$ expression and PCNA labelling indices, perhaps reflecting one of the mechanisms underlying the proliferative processes. ${ }^{3031}$ The TGF $\alpha$ antibody used in the present study was completely absorbed by TGF $\alpha$ peptide in $84 \%$ of patients. The residual staining pattern in the other $16 \%$ of cases was extremely weak (<grade I) and did not interfere with our quantitation. The residual staining may represent cross reactivity with prepro-TGF $\alpha$ (TGF $\alpha$ precursor) or another related peptide which is found on cell membranes and, to a lesser extent, in the cell cytoplasm..$^{2829}$ Another TGF $\alpha$ antibody supplied by $\mathrm{Dr} W$ Gullick has been shown to be completely absorbed by $\mathrm{TGF} \alpha$ peptide (personnal communication).

TGF $\alpha$ mRNA and the peptide have been previously demonstrated in oesophageal adenocarcinomas. ${ }^{32}$ However, the present study is the 
first to show correlation between TGF $\alpha$ expression and the type of mucosal metaplasia as well as dysplasia. Our results are compatible with the clinical reports which have suggested that the intestinal type of Barrett's mucosa has greater malignant potential. ${ }^{12}$

It is also of interest that dysplastic glands with PCNA positive cells in the superficial epithelium show increased intensity of TGF $\alpha$ staining in the same part of the glands. The increased TGF $\alpha$ expression in the superficial epithelium may partly explain the increased proliferation of these cells in high grade dysplasia. We have previously shown that Barrett's mucosa (especially the type with intestinal dysplasia, as well as Barrett's neoplasia) overexpress epidermal growth factor receptors (EGF-R) ${ }^{33}$ Our present observations provide evidence that autocrine or paracrine stimulation may be involved in the neoplastic transformation of the oesophageal mucosa, since production of $\mathrm{TGF} \alpha$ may provide a growth advantage for cells which coexpress EGF-R. Moreover, TGF $\alpha$ is reported to increase production of its own mRNA, so that there may be loss of the negative feedback control which is one of the regulatory mechanisms required to counteract the TGF $\alpha$ autocrine loop. ${ }^{26}$ Failure of these inhibitory mechanisms may be involved in the development of frank neoplasia. ${ }^{3+35}$ In this context we have also previously shown that the mutated anti-oncogene P53, with aberrant function, which may control growth factor expression, is present in $80 \%$ of oesophageal adenocarcinomas. ${ }^{36}$

In conclusion, the findings of this study suggest that immunohistochemical staining with the two antibodies, PC 10 and TGF $\alpha$, can augment routine histological assessment of Barrett's oesophagus by providing additional information regarding patterns of proliferation and, perhaps, also of neoplastic potential, as has been found in other cancers. ${ }^{37-39}$ We are presently assessing the value of TGF $\alpha$ and PCNA labelling as an index of prognosis and clinical outcome in a prospective cohort of patients with Barrett's mucosa.

We gratefully acknowledge the help of Professor D A Levison, Histopathology Department, Guy's Hospital, London, in the preparation of this manuscript. We also acknowledge the technical help of Dr W J Gullick ICRF Oncology Group, London, and thank him for the gift of $26 \mathrm{~T}$ polyclonal TGF $\&$ antibody.

1 Barrett NR. Chronic peptic ulcer of the oesophagus and 'oesophagitis'. Br F Surg 1950; 38: 175-82.

2 Cameron AJ, Zinsmeister AR, Ballard DJ, Carney JA. Prevalence of columnar-lined (Barrett's) esophagus. Gastroenterology 1990; 28: 918-22.

3 Powell J, McConkey CC. Increasing incidence of adenocarcinoma of the gastric cardia and adjacent sites. $B r \mathcal{F}$ Cancer 1990; 62: 440-3.

4 Hesketh PJ, Clapp RW, Doos WG, The increasing frequency of adenocarcinoma of the oesophagus. Cancer 1989; 64: $1-13$.

5 Spechler SJ. Columnar metaplasia of the esophagus (Barrett's epithelium) In: Eastwood G, ed. Premalignant lesions of the gastrointestinal tract. New York: Elsevier Science, 1991.

6 Goyal RK. Columnat cell-lined esophagus. In: Spechler SJ, Goyal RK, eds. Barrett's esophagus. Pathophysiology, diagnosis Goyal RK, eds. Barrett's esophagus. Pathophysiology,
and management. New York; Elsevier, 1985: 1-14.

7 Hall PA, Levison DA. Assessment of cell proliferation in histological material. f Clin Pathol 1990; 43: 18+-92.

8 Quinn CM, Wright NA. The clinical assessment of proliferative and growth in human tumours: evaluation of methods and applications as prognostic variables. F Pathol 1990; 160: 93-102.

9 Bravo R, Frank R, Blundell PA, MacDonald-Bravo H. Cyclin/ PCNA is the auxilliary protein of DNA polymerase alpha. Nature 1987; 326: 515-7

10 Hall PA, Levison DA, Woods AL, Yu C C-W, Kellock IDB, Watkins JA, et al. Proliferating cell nuclear antigen (PCNA) immunolocalisation in paraffin sections: an index of cell proliferation with evidence of deregulated expression in some neoplasms. F Pathol 1990; 162: 285-94.

11 Hall PA, Woods AL. Immunohistochemical markers of cell proliferation: Achievements, problems and prospects. Cell Tissue Kinet 1990; 23: 531-49.

12 Morris GF, Mathews MB. Regulation of proliferating cell nuclear antigen during the cell cycle. $\mathcal{F}$ Cell Biol 1989; 264: 13856-64

13 Waseem NH, Lane DP. Monoclonal antibody analysis of the proliferating cell nuclear antigem (PCNA). Structural conservation and the detection of a nucleolar form. $\mathcal{F}$ Cell Sci 1990; 96: 121-9.

14 Barton CM, Hall PA, Hughes CM, Gullick WJ, Lemoine NR. Transforming growth factor alpha and epidermal growth factor in human pancreatic cancer. 7 Pathol 1991; 163: $111-6$.

15 Tahara E. Growth factors and oncogenes in human gastrointestinal cancer. $\mathcal{F}$ Cancer Res Clin Oncol 1990; 43: 380-4.

16 Jankowski J, McMenemin R, Penston J, Hopwood D Wormsley KG. Abnormal expression of growth regulatory peptides in Barrett's mucosa (abstract). Clin Sci 1991; 81: 663-8.

17 Hamilton SR. Adenocarcinoma in Barrett's oesophagus. In Whitehead R, ed. Gastrointestinal and oesophageal pathology. Edinburgh: Churchill-Livingstone, 1989.

18 Riddell RH, Goldman H, Ransohoff DF, Appelman HD, Fenoglio CM, Haggitt RC, et al. Dysplasia in inflammatory bowel disease: standardised classification with provisional clinical applications. Hum Pathol 1983; 13: 931-68.

19 Steele RJC, Kelly P, Ellul B, Eremin O. Immunohistochemica detection of epidermal growth factor receptors on human colonic carcinomas. Br 7 Cancer 1990; 61: 325-6.

20 Jankowski J, Tregaskis B, Coghill G, Grant A, Hopwood D, Wormsley KG. A comparison of nucleolar organiser region and $\mathrm{Ki}$-67 labelling index (abstract). Clin Sci 1990; 79: 264.

21 Pellish LJ, Hermos JA, Eastwood GL. Cell proliferation in three types of Barrett's epithelium. Gut 1980; 21: 26-31.

22 Bravo $R$, MacDonald-Bravo $M$. Existence of two populations of cyclin/proliferating cell nuclear antigen during the cell cycle. Association with DNA replication sites. 7 Cell Biol 1987; 105: 1549-54.

23 Baserga R. The cell cycle: myths and realities. Cancer Res 1990; 50: 6769-71.

24 Leutz A, Graf T. Relationships between oncogenes and growth control In: Chemical carcinogenesis and mutagenesis II. Cooper CS, Grover PL, eds. Berlin: Springer-Verlag, 1990.

25 Moses HL, Bascom CC, Coffey RJ, Keski-Oja J, Lyons RM Sipes NJ. Transforming growth factors in normal and neoplastic cell growth. Prog Cancer Res Ther 1988; 35 197-202.

26 Derynck R, Goedel DV, Ulrich A, Gutterman JU, Williams RD, Bringman TS, et al. Synthesis of messenger RNAs for transforming growth factors alpha and beta and the epidermal growth factor receptor in human tumors. Cancer Res 1987; 47: 707-12.

27 Di Marco E, Pierce JH, Aaronson SA, Fore PP. Mechanisms by which EGF receptor and the TGF alpha contribute to malignant transformation. Nat Immun Cell Growth Regul 1990; 9: 209-21.

28 Kommos F Winter HO, Von Kleist S, Kohler M, Walker R, Langton $\mathrm{B}$, et al. In situ distribution of the transforming growth factor alpha in the normal human tissues and in malignant tumours of the ovary. $\mathcal{F}$ Pathol 1990; 62: 223-30.

29 Anklesaria P, Teixido J, Laiho M, Pierce JH, Greenberger JS, Masaque J. Cell-cell adhesion mediated by binding of membrane-anchored transforming growth factor alpha to epidermal growth factor receptors promotes cell proliferation. Proc Natl Acad Sci 1990; 87: 3289-93.

30 Chang CD, Ottavio L, Travalli S, Lipson KE, Baserga R. Transcriptional and post transcriptional regulation of the proliferating cell nuclear antigen gene. Mol Cell Biol 1990; 10: 3289-96.

31 Ottavio L, Chang CD, Rizzo MG, Travalli S, Casadevall C. Importance of introns in the growth regulation of $\mathrm{mRNA}$ levels of the proliferating cell nuclear antigen gene. Mol Cell Biol 1990; 10: 303-9.

32 Yoshida K, Kyo E, Tsuda T, Tsujino T, Ito M, Nimoto M, et al. EGF and TGF alpha, the ligands of hyperproduced EGFR in human esophageal carcinoma cells, act as autocrine growth factors. Int $\mathcal{F}$ Cancer $1990 ; 45$ : 131-5

33 Jankowski J, Murphy S, Coghill G, Hopwood D, Wormsley KG. Epidermal growth factor receptors in oesophageal diseases. Gut 1992 (in press).

34 Sikora K. The molecules of cancer. $7 R$ Coll Physicians Lond 1990; 24: 196-205.

35 Goodlad RA, Wright NA. Growth control factors in the gastrointestinal tract. In: Ciclitira RJ, ed. Bailliere's Clinical Gastroenterology. London: Bailliere Tindall 1990.

36 Jankowski J, Coghill G, Hopwood D, Wormsley KG Oncogenes and tumour suppressor genes in oesophageal Oncogenes and tumour suppressor genes in oeso
adenocarcinoma (abstract). Gut 1991; 31: A1205.

37 Jain S, Filipe MI, Hall PA, Waseem NH, Lane DP, Levison DA. Proliferating cell nuclear antigen (PCNA) and its prognostic value in gastric carcinoma. $\mathcal{f}$ (Clin Pathol 1991; 44: 655-9.

38 Woods AL, Hall PA, Shepherd NH, Hanby AM, Waseem $\mathrm{NH}$, Lane DP, et al. The prognostic value of PCNA (proliferating cell nuclear antigen) immunostaining in gastrointestinal lymphomas. F Pathol 1990; 161: 342A

99 Yu CC-W, Woods AL, Levison DA. (1991). The assessment of cellular proliferation by immunohistochemistry: a review of currently available methods and their applications. In Hall P, Levison DA, Wright NA, eds. Assessment of cell proliferation in clinical practice. Heidelberg. Springer-Verlag 1992: $141-53$ 